\title{
Determining the Level of Institutionalization in Family-Owned Shipping Businesses
}

\author{
(1) Kadriye Oya Turhaner ${ }^{1,2}$, (1) Selçuk Nas ${ }^{3}$ \\ ${ }^{1}$ Dokuz Eylül University, Graduate School of Social Science, İzmir, Turkey \\ ${ }^{2}$ Yaşar University, Vocational School, Tourism and Hotel Management Program, İzmir, Turkey \\ ${ }^{3}$ Dokuz Eylül University, Maritime Faculty, Department of Maritime Education, İzmir, Turkey
}

\begin{abstract}
The levels of institutionalization have varied in organizations affecting their success and sustainability in business. The objective of this study is to develop a model for determining the level of institutionalization in which family-owned organizations operate the Level of Institutionalization for Organizations (LIFO) by a collaborative social research. This research contributes to the institutional theory by developing a model for an innovative approach to harmonize family and business at the institutional level with 68 variables derived from institutional theory. It also contributes to family businesses in maritime transportation as the LIFO model was used to determine the institutionalization level of shipowners in general as family-owned businesses. The model is based on the variables in both new and old institutional theory. A semi-constructed questionnaire was conducted among 64 out of a total of 244 of shipping companies registered within the country that operate globally. The data is collected through face to face interviews carried out with the heads of family-owned businesses. The data is used for qualitative content analysis. The results reveal the establishments of these organizations were set on firm bases in the pre-institutionalization level; there were fluctuations in doing business and differing attitutes among organizations in the same field in the semi-institutionalization level; there are bigger issues in the sustainability and insitutionalisation of family in the level of full-institutionalization.
\end{abstract}

\section{Keywords}

Institutional theory, The level of institutionalization, The LIFO model, Maritime Organizations, Family-Owned Businesses, Turkish Shipping Business

\section{Introduction}

"Institutions" can broadly be defined as "structures" that are established. The means of establishment of these structures seems to have varied throughout history. Based on the particular means implemented, the forms and levels of institutions have changed as well. Greenwood et al. [1] categorizes the levels that emerged and gradually developed into four classes namely, "individual", "organization", "field" and "society." According to this categorization, the "individual" level involves the handshake in western societies. The "organization" level entails the use of formal accounting controls while the "field" level comprises of hierarchies of status. Lastly, the "society" level appears as a legal system based upon due process.
Berger and Luckmann [2] point out that the founder's habits are the initial basis for organizational institutionalization. When these habits are shared with the second person in the organization, they form traditions. When the traditions are transferred to third parties participating in the organization, they become sacred orders. Berger and Luckmann [2] also explain that institutionalization is applicable to families as well, wherein spouses with individual habits establish their marriages to create their own traditions which are transferred to their offspring.

Institutionalization is a process in which an organization becomes an institution by social pressures [2]. According to Stewart [3] family businesses are defined as institutions 
that act under the influence of a family's emotional system, ownership system and business system. In these institutions, there is also the issue of the family members' emotional commitment. The business has to be kept under the managerial control.

In family businesses, the structures of family relations shape the business structures. Business-owning families have unique "psychological, behavioral, social, and cognitive" [4] aspects that drive idiosyncratic strategic decisions in the firms they own and operate [5]. Family-owned businesses demonstrate the prevailing corporate model in the world, with a significant impact on the emerging economies and developed nations [6]. Family businesses are of great importance for the global economy. According to the Pricewaterhouse-Coopers Family Business Survey held for 2007-2008, the proportion of registered businesses that are family firms is between 50 and 65\% in European Union countries, $90 \%$ in Latin America, and $95 \%$ in the U.S.A. It is also stated in the survey that these family businesses contribute up to $82 \%$ of the gross national product in Asia, $45 \%$ in North America, $70 \%$ in Latin America, and 65\% in European Union member states. A more recent study carried out by Bain (2019) on Family Capital shows that by the end of 2018, the family businesses ranked among the top 750 family businesses in the world generated annual revenues of more than $\$ 9$ trillion USD, and employed nearly 30 million people [7].

As family businesses dominate the world economy, there must be something unique in them as institutions. Perhaps, it is up to the leader as Selznick [8] states when he writes that the leader of an institution is supposed to define its mission to protect its distinctive character. According to Özen [9], institutionalization is a structure that supports the interest of the empowered to become more solid. Institutional context is shaped by organizations. Some powerful organizations attempt to put their own goals forward and apply their procedures directly into the society as if they are institutional rules of the society at large [10].

As the founders come from different customs as individuals, the institutionalized forms of family-owned businesses greatly differ from one another. Yet they are subject to isomorphism by compelling uniformity resulting from political influence and legitimacy problems, by mimetic responses to environmental uncertainty and by normative uniformity resulting from professionalization. So, organizations start to resemble each other [11].

There are many similarities among family businesses. However, it is not always clear whether there is awareness of institutionalization in these businesses, and whether there are levels in their institutionalization. If so, how can the level of this institutionalization be determined? These questions are considered worth pursuing as there are gaps in the relevant literature on such issues. Therefore, collaborative social research was carried out to develop a model that uses institutional theory as its the theoretical perspective.

The objective of this study is to develop a model for determining the level of institutionalization at which family-owned organizations operate the Level of Institutionalization for Organizations (LIFO) by a collaborative social research. For the purpose of this collaborative social research, the principles of institutional theory were gathered and discussed on how to develop a model for determining the level of institutionalization in family-owned businesses.

The first contribution of this study is that it develops a reliable and applicable model that can be used to assess the level of institutionalization in family-owned businesses. The second contribution is that it provides ship-owners with a guideline to determine their level of institutionalization through regulatory and preventive actions. In implementing this model, family-owned businesses in maritime transportation were preferred since maritime transportation is a dynamic global industry. In the international shipping business and the related activities, focus on commercial, economic, operational and legal subjects is required. Therefore, the success of an organization in the maritime industry depends on the skills and knowledge of its founders and employees [12].

Turkish ship-owners were favored in the study. Sea trade and commercial sea transportation commenced in Turkish maritime at the end of the $19^{\text {th }}$ century. Before that, the sea was the battle ground of the Ottoman Empire [13]. The rule of the Ottoman Empire weakened in the late 1800s and following its collapse and Turkey emerged as its successor in 1923. Turkish ship-owners achieved success and became the $15^{\text {th }}$ biggest fleet in size International Labor Organization in 2016, and maintained the same level up to 2020 according to the Turkish Ministry of Transport and Infrastructure. However, between the 1800s and the 1940s more than a hundred family businesses in the maritime transportation industry became defunct [14]. The third contribution of this study is that it assesses the level of institutionalization of Turkish ship-owners to enhance their self-awareness against obstacles and extinction for sustainability.

The literature reviewed, the model developed and the method of the research, the field of the research the population and sample, the data collection and the methods of analyzing the data are presented together with the findings and discussions. The conclusion, the limitations in the research and the suggestions for further researches are also discussed. 


\section{Literature Review}

Leaptrott [15] explains that institutional theory is not a traditional descriptive approach for examining family businesses to identify their structure and symbolic aspects, but for examining them to understand the relationship of interactive forces between overlapping institutions of the family, business, and ownership, as well as considering many external influences.

Institutional theory goes back to the $1800 \mathrm{~s}$, to the emergence of sociology. The main areas of interest of this theory are theology and government policies at the beginning of an institution's life. Later, organizations were the focus of studies based on micro-corporate values such as rules and procedures, elites, power and leadership, bureaucratization, organization, informal and formal structures, values, norms and attitudes, and formalization. By the 1970s, the theory had moved to a macro level. The central components are corporate policies and the relationship between organizations and the environment, social, culture, structure, effectiveness and continuity, isomorphism, legitimacy, and relations with employees. The theory is divided into "old institutionalization theory" and "new institutionalization theory".

Berger and Luckmann [2] explain that institutionalization is based on business founders: They have their own habits of doing business. Riley [16] states that individuals take beliefs already set in the community without thinking or conducting research. Hinings and Tolbert [17] contributes that the ethics and thoughts of society are formed by the level of economy achieved.

When the habits of business founders are transferred to the second person in the organization, the organization develops its own traditions [2]. Tolbert and Zucker [18] refer to this step in the institutionalization process as objectification. Özen [9] points out that organizations in the same field are limited to the knowledge and resources available at their time of establishment, and resemble each other in reflecting the conditions of that period.

When business grows, the organization expands. Traditions will be dictated to others joining the organization as sacred orders [2]. Tolbert and Zucker [18] call this step sedimentation. Weber [19] states that between elites who have power and authority and employees who obey the elites, there should be a system working bureaucratically like the gears of a machine. Özen [9] asserts that reliability in bureaucracy requires obedience to rules. Selznick [8] explains that social pressure is required for organizations to become institutions such as families or states. However, employees apply their ways of doing business instead of professional practice while those involved in constituting rules attempt to follow the rules with little deviation [2]. Institutionalization is a process in which various social processes, responsibilities, or realities are shifted to a situation in which social thoughts and behaviors transform into a rule-like status [10]. Selznick [20] suggests that when organizations grow, adaptation becomes difficult, so does institutionalization. The level of difficulty in giving up an organization or activity indicates the level of institutionalization of the organization or business [20].

Socialization in the internal environment, informal structures, interests, and personalities of employees are the other aspects of institutionalization [21]. Corporate leadership is solely the creation and maintenance of values. The organizational leader's identity needs to be established, and the leader must evaluate himself or herself as a servant of the organization [2]. The institutionalization of family business requires both the institutionalization of business and of family [22].

The family council is a tool for family institutionalization and sustainability. It is for improving communication and relationships in the family and for determining the conditions of utilization of the family opportunities [22]. In the council with the members of the family and professionals, young members of the family become acquainted with the necessities of the business [23].

Expanding family with in-laws and cousins and the option of delegating business management and leadership to upcoming generations and heirs requires planning [23]. The constitution of the family focuses on this planning as a part of family institutionalization and its sustainability [24].

The relationship with the external environment is a part of institutionalization. The uncertainty of concern for effectiveness on daily work in institutionalized organizations creates considerable stress. Organizations and their leaders may be urged to choose between the results of their technical activities, efficiency, and the legitimacy of the institutional structure [10].

For the benefit of leaders in family businesses, this study aims to provide a model to determine the level of institutionalization with preventive and regulatory actions to overcome problems in their institutions and achieve sustainability for upcoming generations.

\section{The Model and Research Method}

In institutional theory, institutionalization is a process initiated in three stages called habitualization, externalization and internalization [2]. During institutionalization, there is repetition of human knowledge, 
a process referred to as habitualization [14]. The founders of family businesses have naturally unique knowledge and knowledge acquired from doing business. They act similarly in comparable situations with the expectation of economic gain. Yet they are under the influence of technological change and changes in legislation and market forces [18]. All these changes in the environment produce innovations in their habits. Newly altered habits form new traditions in business conduct. These newly set traditions result in renewed sacred orders provided to the members of organizations. The process of institutionalization is thus endless. The study of Berger and Luckmann [2], also describes the process of institutionalization in terms of the three stages defined as habitualization, objectification and sedimentation. Following any innovation, these stages are also the indicators of the level of institutionalization defined as pre, semi and full institutionalization [18].

\subsection{The Model of the Research}

A model developed for the purpose of this study was based on the research gap in understanding what institutionalization means for family-owned businesses; whether it has a crucial value in their transactions, if there are institutionalization levels and if so, how to determine the level of institutionalization of any family business. Guided by these questions, the model is based both on the studies of Berger and Luckmann [2] and Tolbert and Zucker [18] which identify three institutionalization levels and 68 variables from old and new institutional theories.

In the development of the model for the preinstitutionalization level, it is accepted that family businesses are set up by individual founders. In general, there is a follower, either as the very first employee or as the founders' sons. The habits of founders and traditions gathered in the business with the very first employees constitute the starting point of business and their ways of dealing with business interactions. The pre-institutionalization level is compatible with the emergence and development of family businesses.

As part of the development of the model for the semiinstitutionalization level, it is also accepted that as time passes, the numbers of family members working in the family businesses increase, and as the volumes of family businesses expand, so does the number of employees and professionals. Thereby business traditions are passed on as sacred orders to the employees and professionals. The semi-institutionalization level is considered to be the keystone institutionalization process in the development of general and shared social meanings attached to behaviors in business dealings. It is a development that is necessary for enlarging business horizons by expanding actions to contexts beyond their origin. The variables for the semiinstitutionalization level were drawn from work by scholars on institutional theory.

For the full institutionalization level, it is accepted that traditions and sacred orders need to pass onto the next generations as families grow larger by marriage and births. The variables for the full institutionalization level were drawn from work by scholars on institutional theory and from family business management.

Based on the acceptance of the three levels for the model, 37 variables from previous studies on old and new institutional theory are clustered as shown at Table 1.

Based on these variables, 68 determinants of the model are developed and clustered for the LIFO model as preinstitutional level, semi- institutionalization level and fullinstitutionalization level as indicated in Figure 1.

As the research gap is related to family-owned businesses, this study is limited to ship-owning family businesses. For the purpose of this study, empirical research is carried out on Turkish ship-owners. Therefore, the model is titled the Level of institutionalization for organizations model, the LIFO model in short.

\subsection{The Field of Research}

The historical developments in commercial maritime transport at Turkish ports can be divided into three phases [13]. During the first phase in the $16^{\text {th }}$ century, an agreement signed between the Ottoman Emperor and the French king permitted French flagships to trade in Ottoman-Turkish waters. During this phase, Turks were fishermen, ship chandlers, or small boat sailors who loaded and discharged ships at anchorage in bays. During the second phase that occurred between the $17^{\text {th }}$ and $19^{\text {th }}$ centuries, Austrian, Russian, Swedish, Spanish, and Prussian flagships were also permitted to carry out maritime transportation in Ottoman ports. In the third phase, which followed the foundation of the Turkish Republic in 1923, only Turkish flagships were allowed to be active in Turkish ports [13].

The Turkish fleet, which was initially made up of small sailing ships, was upgraded to steamships by the beginning of the $20^{\text {th }}$ century [14]. By 1929, the Turkish Maritime Fleet consisted of 194 ships, 114 of which belonged to private Turkish ship-owners from the Black Sea region. Between 1923 and 1936, the Turkish maritime trade fleet increased further and by 1936, the net tonnage increased to 227,049 tonnes [13]. Beginning with small trade exchanges between Turkish and Black Sea ports, the regular migration of Turks from Romania, Bulgaria, and Greece made the maritime sector very attractive to entrepreneurs in the early 1900 s [13]. Some ship-owners in Istanbul began as ship repairers. They repaired and transformed scrap warships into cargo 
Table 1. LIFO variables in levels of institutionalization

\begin{tabular}{|c|c|c|c|c|c|c|c|c|c|c|c|c|c|c|c|c|c|c|c|c|c|c|}
\hline & $\begin{array}{l}\text { Scholars/ } \\
\text { Variables }\end{array}$ & 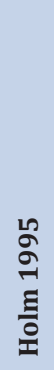 & 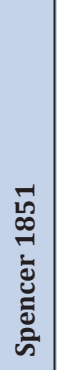 & 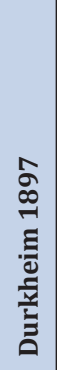 & 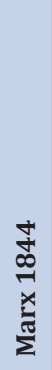 & 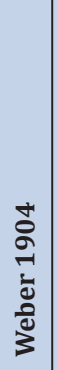 & 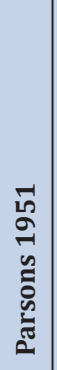 &  &  & $\begin{array}{l}0 \\
0 \\
0 \\
-1 \\
3 \\
0 \\
\vdots \\
0 \\
0\end{array}$ &  &  &  & 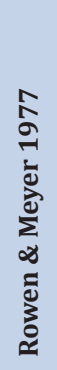 & 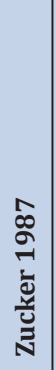 & 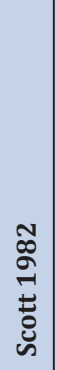 & 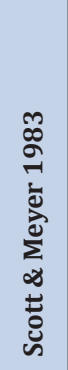 & $\begin{array}{l}\bar{\sigma} \\
\sigma \\
\bar{\sigma} \\
\overline{0} \\
\vdots \\
0 \\
\infty \\
0 \\
0 \\
0 \\
\sum_{0}^{\pi} \\
0\end{array}$ & 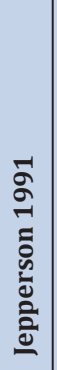 & 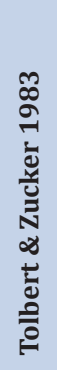 & 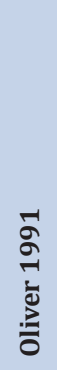 & 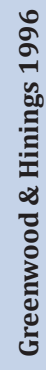 \\
\hline \multirow{14}{*}{ 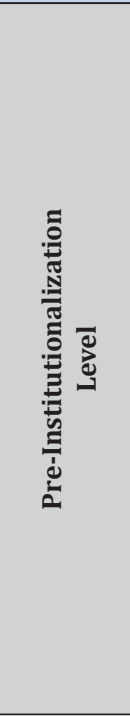 } & Procedures & $\sqrt{ }$ & & & & $\sqrt{ }$ & & & $\sqrt{ }$ & & & & $\sqrt{ }$ & $\sqrt{ }$ & $\sqrt{ }$ & $\sqrt{ }$ & $\sqrt{ }$ & & & $\sqrt{ }$ & $\sqrt{ }$ & $\sqrt{ }$ \\
\hline & Legitimacy & $\sqrt{ }$ & & & & $\sqrt{ }$ & & & & $\sqrt{ }$ & & & & $\sqrt{ }$ & $\sqrt{ }$ & & $\sqrt{ }$ & $\sqrt{ }$ & & & $\sqrt{ }$ & $\sqrt{ }$ \\
\hline & Norms & & & & & & & & & & & & & $\sqrt{ }$ & & & & & $\sqrt{ }$ & & $\sqrt{ }$ & \\
\hline & Structure & & & & & & & & & & & & & $\sqrt{ }$ & $\sqrt{ }$ & & & & $\sqrt{ }$ & $\sqrt{ }$ & & \\
\hline & Formalities & $\sqrt{ }$ & & & & & & & & & & & & & $\sqrt{ }$ & $\sqrt{ }$ & & & & $\sqrt{ }$ & & \\
\hline & Power & & & & $\sqrt{ }$ & $\sqrt{ }$ & & & $\sqrt{ }$ & & & $\sqrt{ }$ & $\sqrt{ }$ & & $\sqrt{ }$ & & & & $\sqrt{ }$ & & & \\
\hline & Bureaucracy & & & & & $\sqrt{ }$ & & & & & & & & $\checkmark$ & & & & & & & & \\
\hline & Obedience & & & & & $\sqrt{ }$ & $\sqrt{ }$ & $\sqrt{ }$ & & & & & & & & & & & & & & \\
\hline & History & & & & & & & & $\sqrt{ }$ & & & $\sqrt{ }$ & & & & $\sqrt{ }$ & & & & $\sqrt{ }$ & & \\
\hline & Processes & & & $\sqrt{ }$ & & & & & & & & & & & $\sqrt{ }$ & $\sqrt{ }$ & & & $\sqrt{ }$ & $\sqrt{ }$ & & \\
\hline & Organization & & & & & & & & & & $\sqrt{ }$ & & & & & & & & & & & \\
\hline & Accountability & & & & & & & & & & & $\sqrt{ }$ & & & & & & & & & & \\
\hline & Habits & & & & & & & & & & & $\sqrt{ }$ & & & & & & & & & & $\sqrt{ }$ \\
\hline & Recruitment & & & & & & & & & & & & & & & & & $\sqrt{ }$ & & $\sqrt{ }$ & & \\
\hline \multirow{17}{*}{ 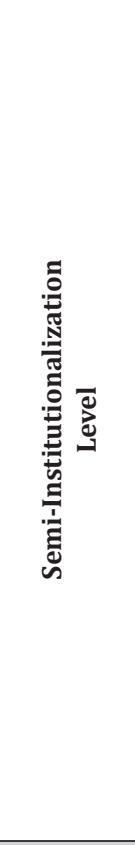 } & Cultural structure & & & & & & $\sqrt{ }$ & & & & & & & & & & & & $\sqrt{ }$ & & & \\
\hline & Impact on social env & & & & & & & & $\sqrt{ }$ & & & & & & & & & $\sqrt{ }$ & & & $\sqrt{ }$ & \\
\hline & Socialization & & & & & & & & $\sqrt{ }$ & & & & & & & & & & $\sqrt{ }$ & & & \\
\hline & Informal structure & & & & & & & & $\sqrt{ }$ & & & & & & & & & & & & & $\sqrt{ }$ \\
\hline & Employee interest & & & & & & & & $\sqrt{ }$ & & & & & & & & & & & & & \\
\hline & Employee personality & & & & & & & & $\sqrt{ }$ & & & & & & & & & $\sqrt{ }$ & & & $\sqrt{ }$ & $\sqrt{ }$ \\
\hline & Social pressure & & & & & & & & $\sqrt{ }$ & & & $\sqrt{ }$ & & & $\sqrt{ }$ & $\sqrt{ }$ & $\sqrt{ }$ & $\sqrt{ }$ & & & $\sqrt{ }$ & $\sqrt{ }$ \\
\hline & Traditions & & & & & & & & & & & $\checkmark$ & $\sqrt{ }$ & & $\sqrt{ }$ & & & & & & $\sqrt{ }$ & \\
\hline & Knowledge & & & & & & & & & & & $\sqrt{ }$ & & & & & & & & & & \\
\hline & Aging & & & & & & & & & & & & $\sqrt{ }$ & & & & & & & & & \\
\hline & Isomorphism & & & & & & & & & & & & & $\sqrt{ }$ & $\sqrt{ }$ & & $\sqrt{ }$ & $\sqrt{ }$ & & & & \\
\hline & Externality & & & & & & & & & & & & & & $\sqrt{ }$ & & & & & $\sqrt{ }$ & & \\
\hline & Conflicts & & & & & & & & & & & & & & & $\sqrt{ }$ & & & & & & $\checkmark$ \\
\hline & De-institution & & & & & & & & & & & & & & & & & & & $\sqrt{ }$ & & $\sqrt{ }$ \\
\hline & Change management & $\sqrt{ }$ & & & & & $\sqrt{ }$ & & $\sqrt{ }$ & & & & $\sqrt{ }$ & & $\sqrt{ }$ & $\sqrt{ }$ & & $\sqrt{ }$ & $\sqrt{ }$ & $\sqrt{ }$ & & $\sqrt{ }$ \\
\hline & Environment & & & & & & & & & & & & & & & & $\sqrt{ }$ & & & & & \\
\hline & Identity & & & & & & & & & & & & & $\sqrt{ }$ & & & & & & & & \\
\hline \multirow{6}{*}{ 韋 } & Efficiency & & & & & & & & & & & & & $\sqrt{ }$ & $\sqrt{ }$ & & & $\sqrt{ }$ & & $\sqrt{ }$ & $\sqrt{ }$ & $\sqrt{ }$ \\
\hline & Leadership & & & & & & & & & & & & & $\sqrt{ }$ & & & & & & & & \\
\hline & Continuity & $\sqrt{ }$ & $\sqrt{ }$ & & & & & & & & $\sqrt{ }$ & & & $\checkmark$ & $\sqrt{ }$ & & & & & $\sqrt{ }$ & & $\checkmark$ \\
\hline & Future & & & & & & & & & & & & & & & & & & & & & \\
\hline & Stability & & & & & & & & & & & & & $\sqrt{ }$ & $\sqrt{ }$ & & & & & & & \\
\hline & Trust & & & & & & & & & & & & & $\sqrt{ }$ & & & & & & & & \\
\hline
\end{tabular}






Figure 1. LIFO model (Level of Institutionalization for Maritime Organizations)

ships in the hope of economic gain and then engaged in maritime transportation. During the Second World War, many Turkish ships were sunk by warships and submarines [11]. After the war, new ships were added to the Turkish fleet. In 1951, there were 136 ships in total, 80 of which were owned privately, and the total net tonnage was 388,873 tonnes [25].

There was increased expansion of the maritime trade in the period between 1923 and 1962. The biggest problem in this period was the age of ships [10]. 
Public maritime transport developed with more significant momentum. However, after 1962, the number of private ship-owners increased [26]. The Turkish fleet had a deadweight tonnage of 7.3 million in 2006, 10.3 million of deadweight tonnage in 2012, and 8.5 million of deadweight tonnage propelling the country to the position of the $14^{\text {th }}$ largest in size and capacity in the world in 2016. However, it should be noted that at present there are 551 ships with 8.3 million of deadweight tonnage in the national registry and 984 vessels with a deadweight tonnage of 20.9 million in the international record with an average age of 18.1 years [27]. In the search for historical development of Turkish shipowning families, it is understood that the first generation of family-owned businesses in Turkish shipping started with wooden ships which were later upgraded to riveted vessels, then steamships, which were in turn upgraded to diesel engines.

During the World Wars, there were economic fluctuations. Turkish ship-owners and their families worked under harsh sea conditions and took risks, sacrificing a great deal for the family to gain better terms. Each new vessel was named after the relevant family patriarchs. Their children were obliged to take over the family business without being offered any other choice. Their workforce and education were predetermined based on the industry needs. Although sons advanced from apprenticeship to mastership in the family business, fathers did not delegate or share power with sons, and the last word always remained with the latter [14].

The experiences in Turkish transportation from ports to international ports [28], development in technical characteristics, tonnage, and values of ships, the increase in amount and value of cargos led to the need for insurance cover. There was a turning point due to environmental determinants [29] that forced Turkish ship-owners to meet classification standards for institutions, insurance companies, and protection and indemnity clubs and their demands [12]. When the businesses grew more prominent, increased branches and more employees were needed, institutional distance became an issue [30]. The founders were obliged to leave the luxury or freedom of independent decision-making, and started to work as a team, obey regulations, establish a system in coordination with the environment, and were forced to be "institutionalized".

\subsection{The Methodology of Research}

The LIFO model was developed for collecting data using face to face interviews with the heads of ship-owning families as a collaborative social research. Contributions from heads of families are considered the most appreciated source for institutional memory, the most accurate and the most precise of points of view. Additionally, their inner thoughts were anticipated to be the focus for the purpose of the empirical research. Due to its nature, the semi-structured questionnaire form was preferred for collecting data because if a question became necessary, it could be included in the research and interviews.

During the development of the LIFO model, a semistructured questionnaire form containing 61 questions was prepared to obtain data. There were four questions for the phrase of institutionalization and its contents, 17 questions for the pre-institutionalization level, 27 questions for the semi-institutionalization level, 13 questions for the full institutionalization level. In this form, open-ended questions and closed-ended questions were used. The closed-ended questions had options of three different scales, namely, completed (yes), not completed (no), and partially completed.

For the external reliability measures, the recommendations provided by LeCompte and Goetz [31], for qualitative researches were applied. For external reliability, all the interviews conducted by a single interviewer, the interviewees were defined clearly, the way and the process of interviews carried out was outlined; the data collection approach and methods of data analysis were described in detail. Similarly, for the internal reliability measures, the data collected was presented directly first and then the discussions were provided in the research. The council consisted of the University of Dokuz Eylul members of the faculty of maritime studies and organization theory studies, the observations provided by the sector were found to be in line with the findings. The model and its levels were defined before data collection.

The reliability and validity of the questionnaire form were tested using two different methods. First, a meeting was arranged with an academic council specialized in maritime logistics and/or organizational theory from among Dokuz Eylül University faculty members. Corrections were made to the questionnaire in line with their criticism and suggestions, and the interview questionnaire form was finalized. Secondly a pilot test was carried out.

The pilot test was conducted with a family-owned shipping organization which took 90 minutes. The pilot study was found satisfactory for developing the model. As a result, the final form of the LIFO model was accepted and the semistructured questionnaire finalized as shown in Table 2.

\subsection{Population and Sample}

The number of members registered at The Chamber of Shipping as ship-owners and ship operators was 1491, some of whom either had no vessels or were inactive in business in 2016. In order to determine the number of members, The Chamber of Shipping provided a list of Turkish flagships 
Table 2. The semi-structured questionnaire for LIFO

\begin{tabular}{|c|c|}
\hline \multicolumn{2}{|c|}{ Part 1} \\
\hline 1 & What is institutionalization according to you? \\
\hline 2 & What are the specifications of an organization that declares itself institutionalized? \\
\hline 3 & Do you think your organization is institutionalized? Yes/No/Partially \\
\hline 4 & What are the reasons of your answer? \\
\hline \multicolumn{2}{|c|}{ Part ll } \\
\hline 5 & Who is the founder? \\
\hline 6 & Is the founder still in management? Which generation currently manages the company? \\
\hline 7 & How many partners established the business? What is the number of partners today? \\
\hline 8 & When was your company established? \\
\hline 9 & What is the legal structure of your company? \\
\hline 10 & What are the fields of activity of your company? \\
\hline 11 & Do you have a logo? Since when do you have logo? Is the logo patented? \\
\hline 12 & Do you have a slogan? \\
\hline 13 & Is there an organization chart? \\
\hline 14 & Have job descriptions for each position been made? \\
\hline 15 & Are the operations and processes standardized? Are the operations written down? \\
\hline 16 & Do you have a handbook for the operations and processes? \\
\hline 17 & Is there a written policy for recruitment? \\
\hline 18 & Is there a practice of recommending new personnel by employees? \\
\hline 19 & Are there any subordinate staffs who have reached management positions? \\
\hline 20 & What are the quality certificates related to the field of activity? \\
\hline 21 & What was the last change in the company? \\
\hline \multicolumn{2}{|c|}{ Part lll } \\
\hline 22 & Is there a strategic plan for the company? What is the strategic plan that is aimed to be realized in the shortest term? \\
\hline 23 & $\begin{array}{l}\text { Do you have vision/mission statements and are they printed for display on the walls? } \\
\text { What is your opinion about the vision/mission statement? }\end{array}$ \\
\hline 24 & Has a precaution plan been made in advance for possible problems? \\
\hline 25 & Does the company have a corporate identity understanding? How would you describe the corporate identity of the company? \\
\hline 26 & Is there an electronic database program used within the company? How do the departments communicate during business operations? \\
\hline 27 & Is there an institutional image determined by the management? How would you describe the corporate image of the company? \\
\hline 28 & Has the company been involved in social responsibility projects? Could you give brief information about your Social Responsibility project? \\
\hline 29 & Does the company have a membership in professional groups? Which is it? \\
\hline 30 & Is market research done? Is an external environment analysis done? \\
\hline 31 & Is information collected about competitors? How are the developments in the industry followed? \\
\hline 32 & How is customer satisfaction measured? How are customer complaints handled? \\
\hline 33 & Are there internal and external audits? How often are they performed? \\
\hline 34 & $\begin{array}{l}\text { Are there any professionals in the management? Is control and management left to professionals? Do business professionals have decision- } \\
\text { making autonomy? }\end{array}$ \\
\hline 35 & $\begin{array}{l}\text { Do managers have a say in recruiting a subordinate staff member? And/or in firing a subordinate employee? Which departments are managed by } \\
\text { family members? }\end{array}$ \\
\hline 36 & Are goals measurable and time-frame set? Do employees work in harmony to achieve the goals of the company? \\
\hline 37 & Is there a clear and written promotion scale and wage scale? Are employees rewarded if corporate goals are achieved? \\
\hline 38 & $\begin{array}{l}\text { What is the employee turnover period? Are employees loyal to their jobs? How would you express the level of commitment/trust of the employees } \\
\text { to the business? }\end{array}$ \\
\hline
\end{tabular}


Table 2. The semi-structured questionnaire for LIFO (Continued)

\begin{tabular}{|l|l|}
\hline \multicolumn{2}{|l|}{ Part lll } \\
\hline 39 & Are employees allowed flexibility in doing work? Is the decision to work overtime in the company easily implemented? \\
\hline 55 & Are there procedures for family members to work in the business? What are these procedures? \\
\hline 56 & Do family members take part even if they do not have sufficient education/skills? \\
\hline 57 & Are there any rules regarding education/gaining experience for the young generation who will take over the management? What are these rules? \\
\hline 58 & How does authority and responsibility work when it comes to family members? \\
\hline 59 & Are there any restrictions for family members' remuneration or expenditure in meeting financial needs? What are the restrictions? \\
\hline 60 & Are family members also subject to performance controls? How is this performance audit done? \\
\hline 61 & $\begin{array}{l}\text { Is there a family council? Who are in the family council? What is the frequency of the family council meeting? Is the family council meeting agenda } \\
\text { being created? Are meeting decisions communicated to all members of the council? }\end{array}$ \\
\hline LIFO: The Level of Institutionalization for Organizations \\
\hline
\end{tabular}

for commercial cargo ships. Since there is a tradition of registering each ship under a different company title, 433 companies were identified as active ship-owners from of this list. To avoid duplication, names with the same addresses and/or phone and/or fax numbers were grouped and a population of 244 ship-owners was determined. Of these, 116 had one vessel, 52 companies had two vessels, 25 companies had three vessels, 18 companies had four vessels, 7 companies had five vessels, and 14 companies had six vessels or more at the time of the study.

In a meeting with the members of The Sea Transporters Association and The Chamber of Shipping in their Izmir Branches, we were advised to focus the sample frame of Turkish ship-owners with at least three vessels and a minimum deadweight of $1000 \mathrm{~m}$ tonnes for each vessel. Thereby the sample was to consist of 64 companies.

\subsection{Data Collection}

Several methods were used to reach the ship-owners: (a) e-mails sent in April through May 2016, (b) phone calls were made as reminders. (c) Several in-person meetings were arranged with some ship-owners during the $6^{\text {th }}$ Joint Commissions Meeting of Commerce of Shipping in Istanbul. (d) A meeting was arranged with the Istanbul Turkish Ship-owners' Association to request their help in obtaining appointments. (e) Another meeting was also set with the Association of Istanbul Ferry Equipment and Agencies to explain the purpose and the objectives of the study as some members of these associations are also ship-owners. Seven monthly meetings of The Chamber of Shipping held in Istanbul (f) and Izmir (g) were attended. Eventually, between April 2016 and May 2017, two interviews in Izmir, and 18 interviews in Istanbul were achieved.

In the interviews conducted through the heads of the families as ship-owners, notes were taken by hand to maintain privacy. Taking notes by voice-recording was not suggested. Interviews were held in their offices to create a familiar setting in the usual workplace [32]. The data was collected by the collaborative social research approached [33]. There was no time limit; the shortest meeting took 60 minutes and the longest 180 minutes. The questions in the questionnaire form were asked one by one, regardless of relevance for consistency and all information provided was taken into consideration.

At the end of each interview, the interviewees were asked whether there were any misleading or missing questions, or information, and according to the ship-owners, whether the questions were satisfactory and meaningful.

\subsection{Methods of Analysis}

The notes taken during interviews were fed into the computer at the end of the day to avoid missing abbreviations and in the notes in the data [12]. The data was collected through open-ended and close-ended questions by the semi-structured questionnaire.

The data obtained through the open-ended questions was analyzed by summarizing content analysis [33]. The data was made into text. The text was then categoried by identifying similar phrases, expressions, patterns, concepts and relationships as codes. These codes were transformed into categorical labels or themes according to [12]. Words, themes, and concepts in the data were subject to coding for analysis [34]. Data coding, finding themes, arranging codes and themes, and defining and interpreting the findings were the four stages applied to conduct content analysis of the questions prepared for the research topic [35]. These codes were then counted as words, and themes [33]. In addition to textual content analysis, the data was analyzed in percentages for quantitative presentation [36].

The data obtained through the close-ended questions was analyzed in quantitative comparison and weighed according to the tonnage of the ships operated by the ship-owners as a percentage of total tonnage in the study. 


\section{Findings and Discussions}

Is the research population is 433 companies; the sample is 64 companies that are Turkish ship-owners with at least three vessels of $1000 \mathrm{~m}$ tonnes and more. The heads of family-owned shipping companies representing 50 companies, ( $78 \%$ of the sample) were interviewed.

Representatives from $78 \%$ of the companies were interviewed during data collection. The heads of families voluntarily talked about the histories of their businesses. In institutionalization, the history of the business and its impact are both required for its social environment [2]. The results of the interviews reveal that $54 \%$ of the companies were established before the 1900 s, $16 \%$ of them between 1960 and $1979,26 \%$ between 1980 and 1999, and 3\% after the year 2000 . The founders of $26 \%$ of these companies were the interviewees themselves, $26 \%$ of the companies were founded by the interviewees' fathers; $1 \%$ by the grandfathers, while $52 \%$ by the great-grandfathers. With regard to the type of work, business operations were related to ship-ownership for $29 \%$, ship operations for $11 \%$. Four percent of them worked in port management; $7 \%$ with tugboats, $7 \%$ in ship broking, 7\% operating shipyards, and $2 \%$ sand transportation. Only $31 \%$ of companies interviewed were involved in non-sea transportation such as oil station operation, ready-mixed concrete production and sales, mining operations, and chemical trade.

In the analysis of the LIFO model, the findings related to each level of institutionalization were presented separately and discussed in line with the literature review.

\subsection{Pre-Institutionalization Level of LIFO Model}

Seventy eight percent of the ship-owners interviewed are incorporated companies while $22 \%$ are limited companies. All these companies have logos, $84 \%$ of which are patented. Identity is a concept observed through the naming of an institution's service [37]. This is also the case for logos, letterheads, vehicles design, and general appearances of buildings, interior decorations, salespersons' behaviors, and managers' profiles. Institutionalization is the acquisition of an identity and is a sensitive and flexible organism as the natural product of social needs and pressures [8]. Seventy percent of these companies define themselves by creating slogans. Corporate identity and corporate image are by-products of the slogans created. Marks and emblems on the funnels of vessels are also a part of the corporate identity. It is an adaptation to the corporate environment [10]. Organizations would be institutionalized by formal structures rationally organized to achieve goals. On the other hand, organizations are subject to social pressures, government expectations, and directives, business practices that dominate the industry, and institutional pressures. Thereby their structures are formed. The formal structure is to determine in advance who is doing what and the processes and forms of systems [8]. With a formal structure, the heads of families of $95 \%$ of the companies stated that their organizational charts were partially defined while $2 \%$ stated that the companies were fully defined. Operational processes in the company are entirely defined by $34 \%$; partially defined in $63 \%$, and undefined in $3 \%$ of the companies. Job descriptions are precisely defined by $71 \%$ and partially by $25 \%$. Written procedures are fully prepared by $87 \%$ and partially by $7 \%$ of the companies. Formal structure allows an organization to be an institution; without social pressure, organizations do not turn into institutions [38]. In line with this view, while doing business in accordance with the job descriptions and personnel adherence, family businesses in sea transportation coordinate relations with the agencies in the external environment, freight holders, parties to the transportation contract, and other organizations such as forwarders under national and international maritime social and legal pressure.

The number of personnel working in the formal structure is one of the elements of institutionalization. Fewer staff indicates a higher level of institutionalization; the ease of innovation will be more effortless in small organizations. The higher the number of organizational functions and the levels of hierarchical order, the higher the institutionalization level [37]. The heads of families stated that there are up to 200 land personnel in $4 \%$, up to 100 in $10 \%$, up to 500 people in $18 \%$, up to 50 people in $22 \%$, and up to 25 people in $45 \%$ of the companies surveyed to carry out their functions. Human resources policies are set by $42 \%$, and partially set by $47 \%$. The existence of human resources policies is a symbol of legal formalization and an example of both standardization and formalization, such as not employing uninsured personnel, stipulating the adequate number of ship personnel, having the necessary documentation of ship personnel.

After data analysis, Figure 2 shows the variables of the preinstitutionalization level of the LIFO model.

\subsection{Semi-Institutionalization Level of LIFO Model}

Twenty-three variables in the LIFO model define the semiinstitutionalization level. The first of these variables is the tools of strategic management. It was determined that $69 \%$ of the companies have strategic plans, while $24 \%$ of them have partial plans. A written mission statement is available in $37 \%$ of the companies, while a written vision is available in $47 \%$. The short-term targets of the companies were expressed in such comments as follows: "Targets that are revised frequently according to the 


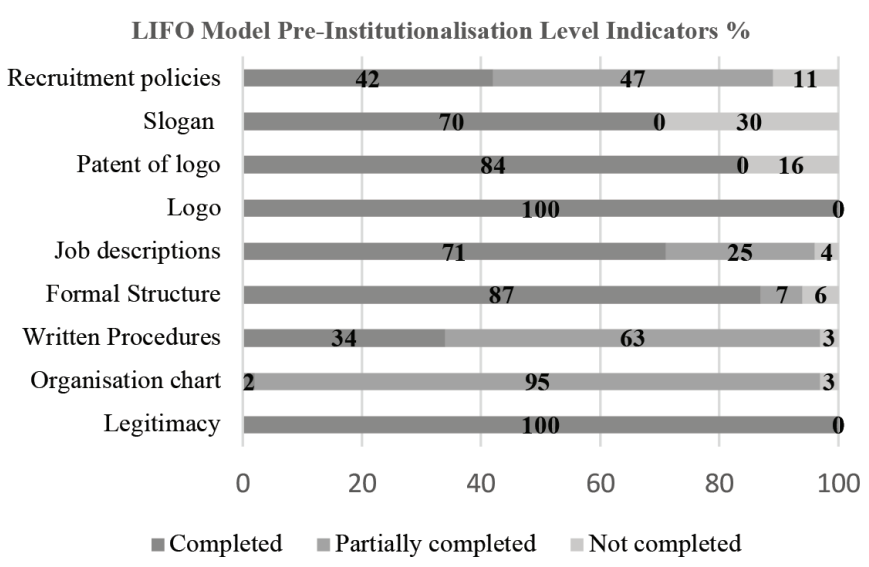

Figure 2. Pre-Institutionalization level indicators of LIFO model

LIFO: The Level of Institutionalization for Organizations

market," "non-existent," "it is an instant decision-making period," "the light at the end of the tunnel is either the approaching train or the unknown," "get rid of the ships," "refresh the fleet, start thinking about buying new ships," "retiring."

Businesses need a corporate identity for their rational structures that allow them to access resources. To form the corporate identity, the first step is to create the corporate image [10]. Corporate image reflects who the company is, how and what they do. Corporate philosophy indicates clues [39]. In this study, the corporate images were expressed by the heads of the families using an average of 11 words. The most commonly used were "reliable" by $23 \%$, "ethical" by $23 \%$, and "reputable" by $16 \%$. The heads of ship-owning companies provided their descriptions of corporate identity by using an average of 17 words. The most commonly used expressions were "having standards" by 12\%, "having respectful reputation" by $12 \%$, "being reliable" by $7 \%$, "Being Honest and Ethical" by 12\%, and "innovative and open to developments" by $12 \%$ of the companies.

In the LIFO model, customers and customer relations are criticized based on several variables. For ship-owners, charterers are also called customers. It has been expressed that charterers are in a stronger position against shipowners due to the crisis suffered since 2008; therefore, ports not pre-visited or cargos not accepted are all in their agendas. The heads of families' state that the charterers' complaints are based on unreturned phone calls regarding vessel delays resulting in "letters of protest" which are eliminated mostly by reducing invoices issued and enhancing service quality. One of the elements of institutionalization is to reduce the dangers of its existence to the organization; therefore, it is generally expected that the companies should provide customer satisfaction, become a learning organization, gain organizational identity, and achieve long term goals instead of short-term ones [37]. In this study, it was found that customer satisfaction metrics are based on the "continuity of charter agreements" and "fewer claims". For the sustainability of the company, market research was carried out on charterers by $94 \%$ of companies using various indexes, publications, and reports. Professional support was requested by only $3 \%$ of the companies. It is understood that personal experience and feelings of the heads of the families are prioritized.

Organizations working in the same field face similar environmental pressures and have structures and functioning parallel to the environmental expectations and challenges. Thus, institutional isomorphism emerges [11]. The companies follow the developments in the industry, so a similar isomorphism emerges. In this study, the coercive isomorphism of DiMaggio and Powel [11] matches Turkish ship-owners' International Safety Management practices and compliance with international conventions is compulsory for maritime transport activities. Another example of compelling and normative isomorphism was tanker management self-assessment applications in tanker companies. As Oliver [40] puts forward, the expansion and balancing of structural innovation in organizations is an attempt to achieve equality between multilateral partners and private interests.

These indicate the changes in the institutional structure to overcome complexity and the reduction or prevention of their effects. Institutional change refers to change in institutional form to ensure continuity [38]. Changes in the economics, insurance, banking, and shipyard arrangements are results of downsizing since 2008. In this study, it was found that Turkish ship-owners prepare themselves for environmental changes by following such sources as print and social media, sectoral publications, and reports, Lloyds List, etc. The meetings in The Chamber of Shipping, Turkish Ship-owners Association and The Baltic and International Maritime Council, professionals, and friends are other sources. As these are the environmental indicators, ship-owners' business policies are revised accordingly.

In this study, $73 \%$ of the companies stated that they prefer warnings and persuasion to manage personnel who resist change for adaptation. Employees' reactions as well as organizational actors to institutional change can be observed. These responses are expressed as passive to active, namely sequencing, submission, compromise, avoidance, resistance and manipulation [40].

Manpower and relationships with employees are crucial aspects for organizations. These aspects are the points 
of focus at the semi-institutionalization level of the LIFO model. It is understood that there are two ways for personnel to address themselves. The formal way, which entails reference by titles such as Mr./Mrs. or Captain, is observed by $44 \%$ of the companies. It can be accepted that the ways of addressing each other are influenced by the values and traditions of the ship-owners' family, business and employees [10]. Normative isomorphism refers to the uniformity of personal behavior patterns, the style of clothing, and the words they use in speech and jokingly, and the way they choose to speak [11].

It was reported that employees have been working for a long term in $68 \%$ of the companies. In $38 \%$ of the companies, some employees have been working for almost 40 years. In $26 \%$ of the companies, employees have been working for 30 years. There are even employees in $1 \%$ of the companies who have been there for more than 40 years. They are considered to be as reliable as the family members. The rules established between two people are transmitted to the third person as sacred orders, and those who contribute to the formation of the rules are more prone to implement them and thus raising the level of institutionalization in the organization [2].

In normative isomorphism, the emergence of uniformity is by professionals and their memberships in professional organizations. The longer they stay in a company and keep their contact with other professionals, the more opinions are exchanged and shared [11]. Disagreements and conflicts between personnel are solved by changes in management methods in $22 \%$ of the companies; by convincing each other peacefully in $23 \%$ of the companies, and by solutions declared by the boss in $55 \%$ of the companies. It was understood that personnel have promotion and job enrichment opportunities. Managerial positions are open to substitutions, and the rate of promotion is $98 \%$. Job enrichment and rotation of personnel are available at $57 \%$ of the companies. Training opportunities are offered to personnel in $70 \%$ of the companies. A monetary reward system was applied to personnel in $85 \%$ of the companies if targets were met. Compliance with individual or organizational objectives is needed to exist as one of the necessary elements of institutionalization [37].

Job enrichment is achieved by working toward the goals of the whole organization [41]. In Turkish ship-owning companies, there is limited employee autonomy. However, $75 \%$ of companies did allow autonomy among professionals but only for operational decisions. Routines are indications of institutionalization. Managers must establish and maintain routines.

The institutional field affects the direction and type of change; therefore, managers should have autonomy [42].
The members of the family manage critical areas such as accounting, finance, human resources, and chartering. The heads of families' state that the delegation of authority to professionals and family members only exists for operational decisions. Having different practices for risk assessment and having a watchful eye on professional from both sides might have conflicting objectives, and having a professional who puts his interest forward or makes decisions that do not match the interest of owner would be costly [43]. The relationships between the principal and the agent are applied to the ship-owner and the professionals employed in the company. In this relationship, a professional is supposed to serve the interests of the business. The agency problem is the base of un-delegated authority [44].

However, there are situations in agency theory where an agent is not sure of the owner's decision due to differences between the objectives of the owner and those of the agent [45]. Such problems could be attributed to the nature of the maritime business; the leader of the family business may need immediate reaction to situations, which would be explained by the contingency approach.

The contingency approach focuses on making instant decisions about how, when, and what will be done depending on the changing conditions [46]. There are no universal principles or methods that are applicable in all cases everywhere. The main task of owners is to determine the most appropriate method to achieve the goal in a situation given.

Owners tend to innovate and identify methods and strategies appropriate to their circumstances. Environmental factors are independent variables. The structure is a dependent variable. Contingency is about providing an active organizational order that will best adapt to the situation characterized by the environment, technology, size, resources, and other factors under which the organization operates. Organizational roles, experiences, beliefs, and ideologies are effective in individuals' perceptions of their environment. At this point, the most critical element is the leader $[47,48]$.

Institutionalization is explained as the process in which social responsibilities and behaviors acquire rule-like status. Seventy one percent of Turkish ship-owners have contributed to social responsibility projects to an extent. These projects included financing a railway bridge, school and faculty classrooms, hospital units, and health centers to carry on the family name. They also stated that they provided private scholarships and supported students.

The findings for the semi-institutionalization level of the LIFO model are shown in Figure 3. 


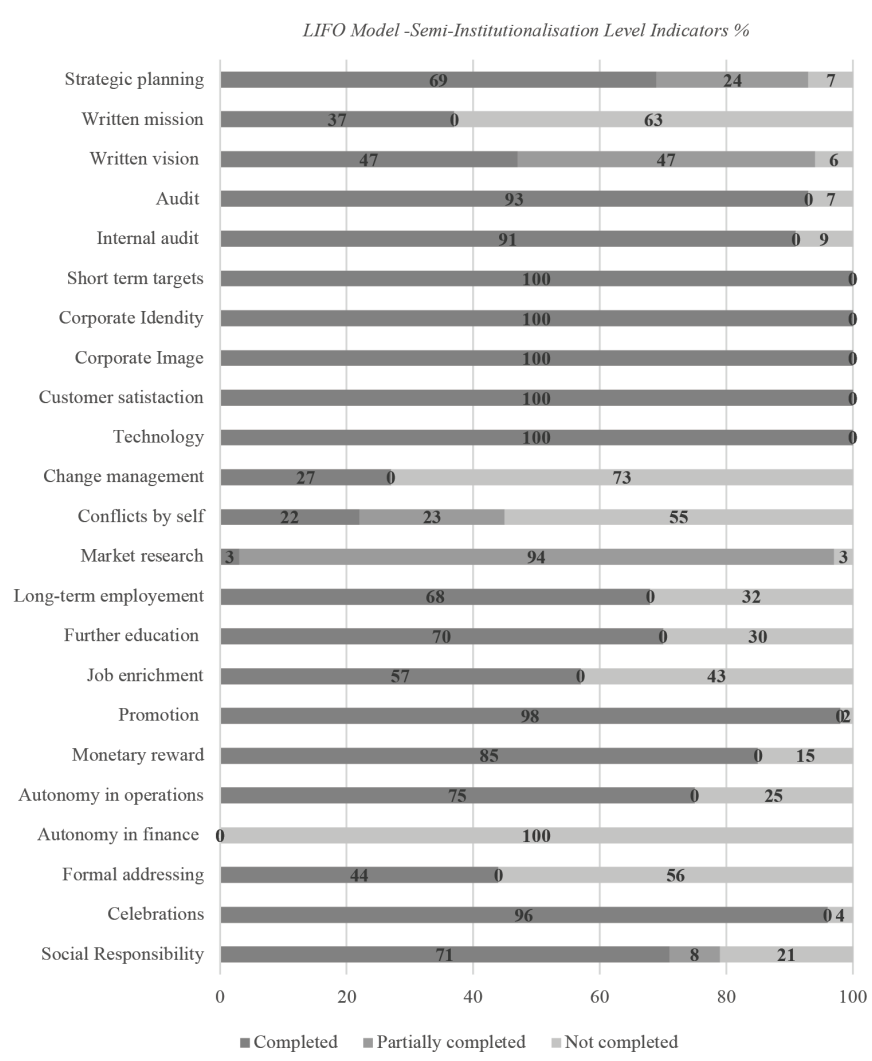

Figure 3. Semi-Institutionalization level indicators of LIFO model

LIFO: The Level of Institutionalization for Organizations

\subsection{Full Institutionalization Level of LIFO Model}

The harmony family and business institutionalization was examined at this level. In the LIFO model, the full institutionalization level is defined based on nine variables and one generation level indicator. At this level, variables related to the age and sustainability of the company is discussed. Three percent of the companies interviewed have been in business for less than 20 years; $26 \%$ for approximately 40 years; $16 \%$ for 60 years, and $54 \%$ for about 100 years. As most companies in the sample are a century old, the level of institutionalization is expected to be high. The reason for this assumption is due to Huntington's study based on the measurement of institutionalization of organizations by adaptability, complexity, autonomy, and compliance. To this end, the age of the organization can measure adaptability. There are three different methods for this measurement: chronic age, generation age, and functional age [37]. Based on the establishment of the companies interviewed, the level of institutionalization was expected to be high according to chronical age.

The power in business management was determined to be in the hands of the $1^{\text {st }}$ generation in $10 \%$ of familyowned businesses; $1^{\text {st }}$ and $2^{\text {nd }}$ generation together in $29 \%$, $2^{\text {nd }}$ generation in $23 \%, 3^{\text {rd }}$ generation in $8 \%, 3^{\text {rd }}$ and $4^{\text {th }}$ generation in $4 \%, 4^{\text {th }}$ generation in $19 \%$, and $5^{\text {th }}$ generation and more in $6 \%$ of the companies surveyed. Despite the increase in organizational generational age, consistency of the management methods may cause failure in organizational adaptation. The level of institutionalization within the organization increases in parallel with the generation change of the leaders. Generation age is a function of chronological age [37]. Despite the changing internal and external environments, the fact that the first and second generations remain in management is a problem [37].

The heads of families define their self-assessed level of institutionalization with an average of 34 words. Fifteen percent of the companies that accept themselves as not being institutionalized maintained that "there would be no institutionalization in maritime business" and "business would not continue without a boss". Further, $47 \%$ of the companies that accept themselves as partially institutionalized stated that "there would be no professional qualified enough to know what he is doing" and "there would be no professional trusted enough to delegate the business to. If such a person existed, she/he would leave to establish his/her own business". Conversely, 39\% of the companies that accepted themselves as fully institutionalized asserted that in their businesses, "job descriptions are made and autonomy borders are drawn", "business is delegated according to these lines" and "professionals are free to make decisions within the limits of their autonomy". Sixtyfive percent of companies had non-family professionals who have been working with a family for more than 25 years. Sixty-three percent of these professionals were also found to be included in the board of directors. The head of families said that these professionals reached their positions by experience from the very beginning of the business mostly at the side of the founder. Unlike other professionals, they mostly have no formal training in business administration, but they are committed to the family with respect and loyalty.

In addition to conducting the board of directors meetings in the manner and frequency required by law, the top management meetings with the chairman of the board of directors were held "frequently" in 30\% of the companies, and similar meetings were held once a month in $10 \%$ of the companies.

There was a designated successor among family members working in $63 \%$ of the companies, $14 \%$ of the companies that had no determined a successor said they would delegate the business to professionals in the future. There were five members on average working for family businesses. It was found that $26 \%$ of the family members working in the enterprises served only as members of the board of directors, 
$26 \%$ in chartering and fleet management, $24 \%$ in finance and accounting management, $7 \%$ as general managers, $5 \%$ in sales and marketing management, $2 \%$ in personnel management, and $2 \%$ in purchasing management.

There was no official performance criterion assessment for family members. However, $79 \%$ of the companies had programs for young family members of undergraduate and graduate level to gain experience in the company.

Families expand through marriage and childbirth. The family constitution is thus crucial for family institutionalization. Setting rules for family constitution is advised [24]. The heads of families in $26 \%$ of the companies stated that these rules are available in written form, in verbal form, or in the formation stage in $8 \%$ of the companies. A family council is a setting in which formal meetings are held; and responsibilities are shared among young members of the family to prepare them for business under the leadership of elder members and professionals [23]. This system was available at $19 \%$ of the companies. The heads of families said that having large weekend lunches/dinners has replaced the meetings recommended for the family council for the preparation of young family members for business and the future in $6 \%$ of the companies.

Findings related to the full institutionalization level are shown in Figure 4.

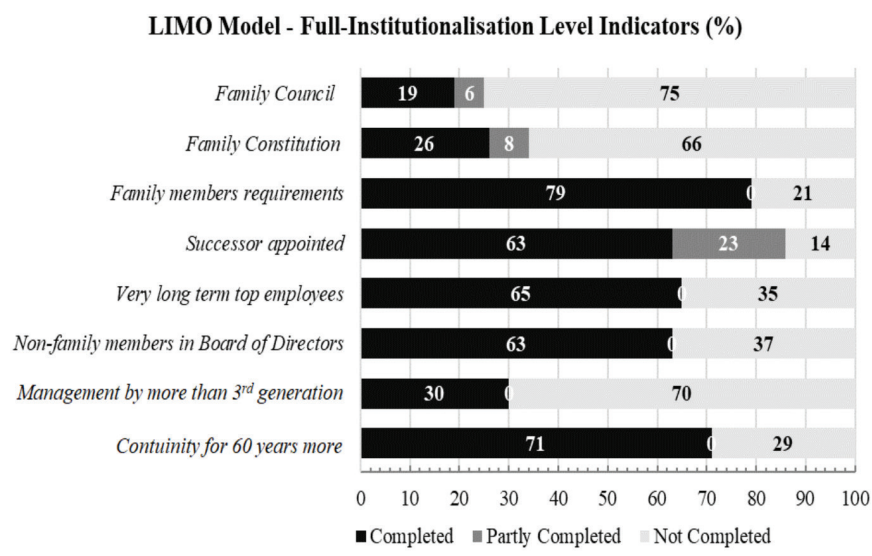

Figure 4. Full-Institutionalization level indicators of LIFO model

\section{Study Limitations}

This is the first study based on the institutionalization of ship-owners as maritime organizations. The heads of the Turkish ship-owners were not willing to contribute to the research; therefore, some of the families/companies in the sample could not be pursued. The interviewees could not be categorized according to the size of their vessels, or the type of cargo they carry, or according to the ports they frequently visit. Some of the interviewees felt irritated answering questions related to family, its members, family constitution and family council. Sea transportation and ship-owners experienced a crisis from 2008 to date thus some of the answers provided by heads might be due to the influence of the financial and emotional stress. The search indicates the results up to 2018. However, according to a report issued by the Chamber of Turkish Shipping, there was a difference of $-7.25 \%$ between 2018 and 2019 and $-3.70 \%$ between 2017 and 2018 is -3.70 in total deadweight of the vessels in Turkish flag and ownerships for 1000 grosston and over. According to the annual report issued by the Ministry of Transport and Infrastructure the Turkish fleet remained the $15^{\text {th }}$ biggest fleet in size in the world between 2016 and 2020. The extent of the business has not been altered much, as the families and their heads are conservatives and the businesses and their attitudes are expeted to remain the same.

\section{Conclusion}

This research contributes to the institutional theory by developing a model for an innovative approach to harmonize family and business at the institutional level with 68 variables derived from institutional theory. With the model, the institutionalization levels of each company can be evaluated independently at all three defined levels.

The study also contributes to family businesses in maritime transportation as the LIFO model was used to determine the institutionalization level of Turkish ship-owners in general as family-owned businesses. Each ship-owner company was evaluated separately, and the data were gathered, and a cross-sectional analysis of the institutionalization of Turkish ship-owner Companies is presented. Using the model, a scale is available to show which variables are missing at each level and which regulatory and preventive activities can be performed by companies.

From the empirical findings and theoretical interpretations reported in this article and in conjunction with consideration of the data, we conclude that a pre-institutionalization level of the LIFO model for Turkish ship-owners was achieved by Turkish ship-owners' companies. The results reveal that the establishment and formalization of these organizations were set on firm bases.

Using the semi-institutionalization level of the LIFO model, it was determined that variables were at different levels across the departments within organizations. The results reveal that there were fluctuations in doing business and differing attitudes among organizations in the same field. The main problem is lack of trust in and the autonomy of professionals. The delegation of management to professionals was impossible for ship-owners. Agency theory can explain this result. 
The companies and families have not achieved the determinants of the full institutionalization level of the LIFO model. The results reveal that there are already existing problems or problems that are likely to emerge very soon in family sustainability and institutionalization. The main problems can be summarized as follows: Family members and businesses face uncertainty due to the family rules, lack of performance/payment balance for family members, the lack of participation of the family council in the preparation and development of young family members for business continuity, reluctance and lack of confidence in delegating authority to younger generations, as is seen in the agency theory. The head of the family believes that he can evaluate the situation best by him/herself, and due to the nature of the sea, only s/he can determine the right direction for the company interests as is seen in the contingency theory theoretical perspective.

When the evaluated findings were shared with the participating companies, they stated that the results reached were very satisfactory and gave guidance. As intended by this study, the LIFO model can be used not only in maritime organizations but also in structures in which there are many family business arrangements.

\section{Recommendations for Further Research}

A similar study can be carried out by sorting companies by cargo carried and ports visited by ship-owner family businesses. The LIFO model can be applied to Turkish coaster-owner family businesses, which are nowadays under legislative development and on the governmental agenda.

\section{Authorship Contributions}

Concept design: K.O. Turhaner, S. Nas, Data Collection or Processing: K.O. Turhaner, S. Nas, Analysis or Interpretation: K.O. Turhaner, S. Nas, Literature Review: K.O. Turhaner, S. Nas, Writing, Reviewing and Editing: K.O. Turhaner, S. Nas.

Funding: The authors declared that this study received no financial support.

\section{References}

[1] R. Greenwood, C. Oliver, K. Sahlin-Andersson, and R. Suddaby. The SAGE Handbook of Organizational Institutionalism. London: SAGE Publications, 2008.

[2] P. Berger, and T. Luckmann. The Social Construction of Reality. New York: Penguin Books, 1996.

[3] L.M. Stewart, "Exploring the impact of type of family care on work-family and family-work conflict," Journal of Family, vol. 34, pp. 113-138, April 2012.

[4] L.R. Gomez-Mejia, C. Cruz, P. Berrone, and J. Castro, "The bind that ties: Socioemotional wealth preservation in family firms," Academy of Management Annals, vol. 5, pp. 653-707, Jun 2011.
[5] M. Carney, "Corporate governance and competitive advantage in family-controlled firms," Entrepreneurship Theory and Practice, vol. 29, pp. 249-265, May 2005.

[6] S. Pramodita, J.J. Chrisman and K.E. Gersick, "25 years of family business review: reflections on the past and perspectives for the future," Family Business Review, vol. 25, pp. 5-15, March 2012.

[7] Family Capital. "The World's Top 750 Family Businesses Ranking”. [Online]. Available: https://www.famcap.com/the-worlds-750biggest-family-businesses/. [Accessed: Aug. 17, 2020].

[8] P. Selznick, "Institutionalism 'old' and 'new'," Administrative Science Quarterly, vol. 41, pp. 270-277, Jun 1996.

[9] Ş. Özen, New Institutional Theory: New Horizons and New Problems in Analyzing Organizations, S. Sargut and Ş. Özen (editors), Organization Theories, Istanbul: İmge Publications, 2017: 237-330

[10] J.W Meyer and B. Rowan, "Institutionalized organizations: Formal structure as myth and ceremony," American Journal of Sociology, vol. 83, pp. 340-363, Sep 1977. https://www.jstor. org/stable/2778293

[11] P.J. DiMaggio and W.W. Powel, Introduction to the new institutionalism and organizational analysis. Chicago: University of Chicago Press, 1991.

[12] S. Nas, Analysis of Ship Masters' Individual Decision-Making Process for the Management of Ship Operations and Application of an Integrated Model, PhD Thesis, İzmir: Dokuz Eylül University Graduate School of Social Sciences, İzmir, Turkey, 2006.

[13] M. Hergüner, A review of seafaring in the early years of Turkish Republic, 1923-1930. Istanbul: Chamber of Shipping Publications, 2002.

[14] 0. Öndeș, History of ferry shipowners and agencies. İstanbul: Chamber of Shipping Publications, 2016.

[15] J. Leaptrott, "An institutional theory view of the family business," Family Business Review, vol. 18, pp. 215-228, Sep 2005.

[16] A. Riley, The Social Thought of Emile Durkheim, London: Sage Publications, 2015.

[17] C.R. Hinings and P.S. Tolbert. Organizational Institutionalism and Sociology: A Reflection. (Editor, R. Greenwood, C. Oliver, R. Suddaby, \& K. S. Anderssons) The SAGE Handbook of Organizational Institutionalism: Thousand Oaks, CA: Sage Publications, 2008:473-474.

[18] P.S. Tolbert, and L.G. Zucker, The institutionalization of Institutional Theory, in S. Clegg, C. Hardy and W.W. Nord (editors), Handbook of organization studies. London: Sage Publications Inc, 1996:175-190.

[19] M. Weber, Bureaucracy and Authority: Weber 1864-1920. (Translation B. Akın), İstanbul: Address Publications, 2006:1-59.

[20] P. Selznick, Leadership in administration: a sociological interpretation. Evanston, IL: Row, Peterson, 1957.

[21] C.R. Hinings, and R. Greenwood, Institutions and Ideals: Philip Selznick's Legacy for Organizational Studies Research in the Sociology of Organizations. 44: 121-148. Emerald Group Publishing, 2015, pp. 121.

[22] D. Bork, D.T. Jaffe, L. Dashew, and Q.G. Heisler, Working with Family Businesses. San Francisco, CA: Jossey-Bass Publications, 1996. 
[23] N. Alayoğlu, Management and Institutionalization in Family Businesses. Istanbul: MÜSİAD Publications, 2003.

[24] H. Alacaklığlu, Corporate Management and Family Companies. İstanbul: Resital Publications, 2009.

[25] N. Olgaç, A General View to Turkish Maritime. Istanbul: Naval Forces Command Publications, 1952.

[26] G.A.Cerit, Historical Overview of Turkish Maritime Transportation Sector with its Corporate Structure Legal Frameworks and Indicators: Istanbul: Chamber of Shipping Publications, 2007.

[27] B. Köseoğlu, A.C. Töz, and C. Şakar, "Flag Choice Behavior in the Turkish Merchant Fleet: A Model Proposal with Artificial Neural Network Approach," Journal of Eta Maritime Science, vol. 5, pp. 186-200, Jun 2017.

[28] A. Göçer, C.A. Vural, and D.A. Deveci, "Drivers of and barriers against market orientation: a study of Turkish container ports," Maritime Economics and Logistics, vol. 21, pp. 278-305, Nov 2017.

[29] C.K. Cetin, and A.G. Cerit, "Organizational effectiveness at seaports: a systems approach," Maritime Policy and Management, vol. 37, pp. 195-219, May 2010.

[30] A.S. Gaur, A. Delios, and K. Singh, "Institutional Environments, Staffing Strategies, and Subsidiary Performance," Journal of Management, vol. 33, pp. 611-636, Aug 2007.

[31] M.D. LeCompte and J.P. Goetz, "Problems of Reliability and Validity In Ethnographic Research," Review of Educational Research, vol. 52 pp. 31-60, March 1982.

[32] M.J. Parada, M. Nordqvist, and A. Gimeno, "Institutionalizing the Family Business: The Role of Professionals Associations in Fostering a Change of Values," Family Business Review, vol. 23 pp. 355-372, Aug 2010.

[33] B.L. Berg, H. Lune, Qualitative research methods in the social sciences. Konya: Pearson Publications, 2015.

[34] A.L. Strauss, and J.M. Corbin, Basics of Qualitative Research: Grounded Theory Procedures and Techniques, Newbury Park, CA: Sage Publications Inc, 1990.

[35] Collins, A. B. 1999. A Case Study of Instructional Supervision at A Private School. PhD Thesis. Ankara: Middle East Techinical University Social Sciences Institute.
[36] N. Bilgin, Content Analysis Techniques and Case Studies in Social Sciences. Ankara: Siyasal Publications, 2006.

[37] S.P. Huntington, Political Order in Changing Societies. New Haven: Yale University Press, 1968.

[38] R. Jepperson, Institutions, Institutional Effects and Institutionalism, in W.W. Powell and P.J. DiMaggio, (editors). The New Institutionalism In Organizational Analysis, Chicago: University of Chicago Press, 1991, pp. 143-161.

[39] W. Olins, Corporate Identity: Making Business Strategy Visible Through Design. Harvard Business School Press, 1990.

[40] C. Oliver, Strategic Responses to Institutionalized Processes. Academy of Management Review, vol. 16 pp. 145-147, Jan 1991. http://www.jstor.org/stable/258610

[41] T. Koçel, Business management. İstanbul: Beta Publications, 2010.

[42] L.G. Zucker, "Institutional theories of organization," Annual Review of Sociology, vol. 13, pp. 443-464, 1987. https://doi. org/10.1146/annurev.so.13.080187.002303

[43] V.D. Dragomir, "Highlights for a history of corporate governance," European Journal of Management, Mar 2008, in press. https:// ssrn.com/abstract $=1114045$.

[44] M. Dil and G.E. Gümüștekin, Contribution of agency theory to family businesses and a model proposal. in T. Koçel (editor). 3. Family Business Congress Book (301-312), Istanbul: Istanbul Kültür University, 2018.

[45] K. M. Eisenhardt, Agency theory: an assessment and review. Academy of management review. vol. 14 pp. 57-74, Jan 1979.

[46] H.L Tosi, Theories of organization. Thousand Oaks, CA: Sage Publications Inc, 2008.

[47] J.Pfeffer, Mergeras a responseto organizational interdependence. Administrative Science Quarterly, vol. 17, pp. 382-394, Sep 1972.

[48] R.E. Miles and C.C. Snow, “Designing Strategic Human Resources Systems” Organizational Dynamics, vol. 13 pp. 36-52, Sep 1984. 